\title{
Erratum to: Distribution of Organic Microcontaminants, Butyltins, and Metals in Mussels From the Estuary of Bilbao
}

Luis Bartolomé • Nestor Etxebarria • Irantzu Martínez-Arkarazo •

Juan Carlos Raposo • Aresatz Usobiaga • Olatz Zuloaga • Damien Raingeard •

Maren Ortiz-Zarragoitia $\cdot$ Miren P. Cajaraville

Published online: 23 May 2010

(C) Springer Science+Business Media, LLC 2010

\section{Erratum to: Arch Environ Contam Toxicol \\ DOI 10.1007/s00244-009-9458-9}

The authors wish to consider an erratum to correct the omission of one of the co-authors of the work, Dr. Maren
Ortiz-Zarragoitia. Thus, Maren Ortiz-Zarragoitia is author no. 8, before Miren P. Cajaraville, and with the same affiliation as Miren P. Cajaraville at the Department of Zoology and Cell Biology, Euskal Herriko Unibertsitatea, 48080 Bilbao, Basque Country, Spain.

The online version of the original article can be found under doi:10.1007/s00244-009-9458-9.

L. Bartolomé $(\bowtie) \cdot$ N. Etxebarria · I. Martínez-Arkarazo

J. C. Raposo · A. Usobiaga · O. Zuloaga

Department of Analytical Chemistry, Euskal Herriko

Unibertsitatea, 48080 Bilbao, Basque Country, Spain

e-mail: luis.bartolome@ehu.es

D. Raingeard · M. Ortiz-Zarragoitia - M. P. Cajaraville Department of Zoology and Cell Biology, Euskal Herriko

Unibertsitatea, 48080 Bilbao, Basque Country, Spain 